\title{
IAMJ
}

INTERNATIONAL

AYURVEDIC

MEDICAL JOURNAL

\section{A LITERARY REVIEW OF VAATASTHEELA MOOTRAGHATA AND ITS MANAGEMENT W.S.R BPH}

\section{Sweta Rautela}

PG Scholar, Dept. of Shalya Tantra, GurukulCampus, Uttarakhand Ayurved University, Haridwar, Uttarakhand, India

Corresponding Author: goldieswet@gmail.com

\section{https://doi.org/10.46607/iamj1409052021}

(Published Online: May 2021)

Open Access

(C) International Ayurvedic Medical Journal, India 2021

Article Received: 17/04/2021 - Peer Reviewed: 04/05/2021 - Accepted for Publication: 05/05/2021

Check for updates

\section{ABSTRACT}

Acharya Sushruta, known as the father of ancient surgery, has given immense contribution in the field of surgery. One of the biggest contributions by Acharya Sushruta comes in the form of urological disorders mentioned by him in his classical text, Sushruta Samhita. He has contributed separate chapters describing the ailments of urinary system. These are mentioned under the chapters related to Mootrakricha (dysuria), Mootraghata (urinary retention) and Ashmari (Renal stone). The description of urinary retention-based symptoms is dealt in the chapter of Mootraghata. The diseases Mootraghata and Mootrakricha both are related to Mootravaha Srotas (channels of urinary system) but in Mootraghata, there is obstruction/retention of urine while in Mootrakricha there is excessive pain during urination. Both of these diseases are mentioned in Uttar Tantra in Sushruta Samhita. Mootraghata can be compared with group of obstructive urinary disorders. It includes twelve subtypes, among them is Vaatastheela. Due to the anatomical mal-alignment and physiological disturbances it causes, it seems quite similar to BPH. BPH is a non -malignant enlargement of the prostate gland in elderly males. It is commonly found in age group above 50. About half of the men in their fifties and about $90 \%$ men above the age of 80 suffer from this disease. Peak incidence is 60-70 age group. BPH has a multi-factorial pathogenesis caused by involvement of prostate and bladder as well as disturbance in Hypothalamus-pituitary-gonad Axis. 
Keywords: Mootraghata, Vaatastheela, $\mathrm{BPH}$

\section{INTRODUCTION}

Mootraghata is defined as "Mootraghate Mootravarodh" (obstruction to flow of urine). General symptom of Mootraghata is Mootraghataee $\mathrm{Tu}$ Vibandhaubalaban Kricchatwamlpamiti ${ }^{2}$. (condition where retention of urine is the cardinal feature). The word Mootraghata comprises of 2 words "Mootra" and "Aghata" which stands for low urine output due to obstruction in the passage of urine. Acharya Chara$k a$ has mentioned 13 types of Mootraghata while Acharya Sushruta has mentioned 12 types of Mootraghata only. Vaatastheela $(\mathrm{BPH})$, one of the types of mutraghata is found to have close resemblance to $\mathrm{BPH}$ in modern parlance based on its sign and symptoms.

Acharya Sushruta has described Vaatstheela (BPH) as a condition which occurs due to vitiation of Apaan Vaayu and this vitiated Vaata occupies the space in between the Shakrith Marga (rectum) and Basti Pradesha (urinary bladder) leading to the formation of Ashteelavat Ghana Granthi (stone like, dense and firm glandular growth) which is Achala (movable)and Unnata (elevated) ${ }^{3}$. This growth causes Vin, Mutra and Anila Sanga (obstruction to the flow of urine, faeces and flatus) and also Adhyamana and Vedana at Basti Pradesha (distension of bladder and pain in the bladder). BPH correlates with Vatastheela, having similarities in symptoms and surgical anatomy. As the nature of pathology in both the conditions is similar i.e. obstruction to the outflow of urine. In $\mathrm{Vaa}$ tastheela it is due to Astheela Vat Granthi" reason being vitiated Vaata Dosha and in BPH is due to an enlarged firm prostate gland. It is mentioned by Acharya Sushruta that the vitiated Vaata Dosha resides in between Sharkrit Marga and Basti Pradesh and it is also seen that Prostate is the only structure lying between lower part of urinary bladder and rectum in male .Also Acharya Dalhana had mentioned the structure and locations of Paurusha Granthi (prostate gland ) in the body i.e. in Bastimoola Pradesha 4 The Vaatstheela Mootrghata reflects the symptoms of lower urinary tract as retention of urine, incomplete voiding, dribbling, dysuria. So, on the basis of these similarities, Vaatastheela can be co-related with BPH in modern view. Acharya Charaka has given the name "Astheela" for the same disease.

\section{Materials and Methods}

For the present study, various Samhitas like Sushruta Samhita, Charak Samhita, research articles were reviewed

Nidana $^{5}$

There is no mention of any specific etiological factors of Vaatstheela or Mootraghata so in general the etiological factors for Mootrakrichha can be considered for the same which are as follows:

Ativyayama (Excessive exercise), Teekshna aushadha (drugs having strong potency) Rukshamadya prasanga (Excessive consumption of dry alcohol), Nityadruta prishtyanat (Regularly riding on the back of fast moving animals), Adhyashana (eating before digestion of previous meal, Ajeernat (Indigestion).All of these factors are Vaata Prakopaka and thus should be avoided.

\section{Samprapti ${ }^{6}$}

Acharya Sushruta states the importance of Pratiloma Vayu in the BastiRogas (disorders of urinary system) while Acharya Dalhana quotes that Vata is the main factor in the pathogenesis of Mootraghata. The opinion of Acharya Charaka is that when Amavisha (Toxins) gets localized in the urine,leads to Mootra Rogas.

Samprapti Ghataka: The main Doshas involved are all the three doshas predominantly Vaata Dosha. The Dushyav are Rasa(fluid), Rakta (blood). Kleda (slogh), Sved (sweat), Mootra (urine) (Depends on different clinical entities). The Jatharagni (digestive fire) is Mandhya (diminished) in the disease. Roga Marga is Madhyma. The disease is: Kriccha-Sadhya (hard to treat).

\section{Lakshana}

Acharya Sushruta has explained the following features of Vaatastheela:

Ashteelavat Ghana Granthi (stone like, dense and 
firm glandular growth) which is Achala (movable)and Unnata (elevated). This growth causes Vin, Mutra and Anila Sanga (obstruction to the flow of urine, faeces and flatus) and also Adhyamana (Distension of urinary bladder) and Vedana Ch Prabustou (extreme Pain)

Acharya Charaka has explained vitiated Vaayu obstructing the Basti Mukha and Guda leads to prominent mobile extremely painfulstone like mass which is in turn causes obstruction to the passage of urine and faeces ${ }^{7}$.

\section{Chikitsa}

Acharya Sushruta has mentioned under Mootraghat chikitsa the use of various Kashaya (decoction), Kalka (pastes), Ghritha (medicated ghee), Bhakshya (edibles), Lehya, paya (milk recopies), Kshara (alkalies), Madya (wine), Sweda (sudation) therapies and Uttarbasti should be advised; In addition, Ashmari nashaka and forUdavartahar Yogas should also be advised for alleviation of Mootraghata

\section{Pathya- Apathya ${ }^{9}$}

Pathya- Abhyanga (Oil massage), Snehana (Medicated ghritha and oil internally), Virechana (Oily purgatives), Basti (Retention and evacuation enema) Uttarbasti (Retention bladder wash), Swedana (Induction of sweating) Avagaahana (Tub bath) These all activities are advisable.

Beneficial Diet-Sura, Aasava, Arishta, Udad, Moong, Masoor, Talphala, milk and its products are advisable. Apathya - Virudha (Incompatible diet), Exercise, Dry and fermented food items, Constipated food item, Vyavaya (overindulged in sexual act and suppression of urination). Restriction of these activities is advised to the diseased.

Upadrava/Arishta: If the pain of Astheela moves upwards towards heart causing pain and anorexia, it all indicates death beyond doubt.

\section{MODERN REVIEW OF BPH}

"He was very often, both in the day and the night, forced to make water, seldom in any quantity, because he could not retain it long enough" - Edward Hyde (First earl of Clarendon), 1759.

The male urinary system consists of various organs which are - kidney, ureter, prostate, urinary bladder and urethra. The prostate derived from Greek word "prostates"- which means "one who stands before ", "protector "or, "guardian". Prostate is an accessory gland of male reproductive system ${ }^{10}$.It can be defined as non -malignant enlargement of the prostate gland, due to the excessive growth. It is a condition in which there is increase in size of prostate inside its capsule which exerts pressure on the urethra leading to the obstruction to the flow of urine. This disorder leads to urinary symptoms in elderly males, $90 \%$ of the males over 80 years of age have histological evidence of BPH (Fang-Liu, 1993) ${ }^{11}$. In India BPH is a common pathological condition with an incidence of 95.97 and 95.3\% of prostatic nodules but its cause is not known definitely. Various theories are given to explain its occurrence like:

THE HORMONE THEORY ${ }^{12}$ - An imbalance between the androgen and oestrogen might be the cause for this hyperplasia. It might be that the androgen diminishes as age increases and in comparison, to that the quantity of estrogen does not decrease equally. So, the prostate may have enlarged due to relative predominance of estrogenic hormone.

THE NEOPLASTIC THEORY - Acc. to this theory, benign enlargement of prostate is considered as neoplasm i.e. adenoma or adenomyoma of the gland. As there may be considerable fibrous tissue involved in such neoplasm, it may also be fibro-myo-adenoma.

\section{Pathophysiology of BPH:}

BPH usually involves median and lateral lobes or one of them. It involves adenoma zones of prostate, i.e. sub mucosal gland. Median lobe enlarges into the bladder while the Lateral ones narrow the urethra causing obstruction. Urethra gets elongated and narrowed. Enlarged prostate compresses the prostatic venous plexus causing congestion, called as vesicle piles leading to Haematuria. Back pressure causes hydro-ureter and hydro -nephrosis. Secondary ascending infection can cause acute or chronic pyelo nephritis. Often severe obstruction can lead to obstruction with renal failure.

\section{Clinical Features of $\mathbf{B P H}^{\mathbf{1 3}}$ :}

There is no direct relation between the degree of enlargement and the severity of symptoms. Frequency, 
Urgency, Hesitancy, Dysuria, Nocturia and Pain are seen. Prostatism (Group of symptoms of disturbed voiding) in aging individuals. The basic problem is bladder outflow obstruction.

\section{Complications of BPH}

Retention of urine (Acute and chronic), Recurrent urinary tract infections (UTI), Bladder Calculi (Stones), Secondary bladder instability, Renal impairment (Insufficiency), Hematuria

Diagnosis of BPH -

Assessment of IPSS (International prostate symptom score)

\section{DRE - Digital Rectal Examination}

\section{Investigations:}

Urine - analysis (Routine and microscopic examination, $\mathrm{Hb} \%$, ESR, blood urea , serum creatinine, Blood NPN estimation), PSA (prostatic specific antigen, Prostatic acid phosphates (PAP) (Normal range 1-3 KA units ), USG (abdomen and pelvis), Post void residual (PVR) estimation, Uroflowmetry (Urinary Flow rate) and Urodynamic-pressure- Flow studies can be done.

\section{Differential diagnosis}

The disease is differentiated with the following diseases:

Stricture urethra, A prostate, Bladder tumor, Bladder neck stenos is, bladder neck hypertrophy, Idiopathic detrusor activity, Neurological causes of retention of urine like diabetes, Parkinson `s disease

\section{Management}

\section{(Conservative)}

Regular prostatic massages might be useful in overcoming prostatic congestion. The patient should be advised to not intake a large amount of fluid in a short duration of time. On feeling the patient should void as soon as he feels to do so as to prevent the over distension of the bladder. Cold weather and immobility may increase the risk of urine retention, thus keeping warm and exercising may be useful. Avoiding alcohol, coffee, tea and other liquids, after the evening are helpful.

\section{(Medical)}

Alpha- blocking agents (Terazocin, Prazocin), Testosterone sparing agents like 5 alpha-reductase and Tes- tosterone ablation agents (Diethyl stilbestrol, Flutamide, progesterone derivatives) These are the most common and useful medical drugs available at this time for treatment.

\section{(Surgical)}

The prostate can be approached- Trans urethral, supra pubic, perinea and retro pubic. Following are the conventional surgical methods used for surgical management of prostate.

Transurethral Resection of Prostate (TURP), Suprapubic transvesical prostatectomy, Simple retro pubic prostatectomy, Perinea prostatectomy

Bladder neck incision that is done for small size prostate (size under $20 \mathrm{gm}$ )

Open prostatectomy for large sized gland size around 80-100 gm)

Minimally invasive treatment methods include. Transurethral laser- induced prostatectomy (TULIP), Transurethral electro vaporization of the prostate, Microwavic Hyperthermia treatment with temperature (40-45), Transurethral needle ablation of the prostate (TUNA), Intraurethral stents placement at prostatic urethra, Transurethral balloon dilation of the prostate

\section{Post Operative Complication of Prostatectomy:}

Hemorrhage, Infection, Epididymitis, Renal failure, Cardiac and respiratory complications, Bladder neck stricture, Retrograde ejaculation and impotency, Urethralstricture,

\section{DISCUSSION}

From the above discussion we can conclude that urological disorders are form an integral part of medical science and were important in the past too. Our ancient texts have also described various pathologies prevalent in the ancient times related to the urinary system and analyzing the above study, we come to know the urinary disorders mention in the ancient times bear resemblance to the present ones. We can see that Vaatastheela Vyadhi mentioned in ancient textbooks bear much resemblance to symptoms of BPH. Acharya Sushruta has given a proper line of treatment of Vaatastheela.BPH as we see is a very complicated process and disease and management seems very typical as due to the age group of the pa- 
tient as well as the multi factorial pathogenesis seen its origin. Its management is through operative way, but this method too has very side effects. So, a new approach regarding the treatment is sincerely required. And as we can see as mentioned in many of our textbooks that there is a wide range of treatment prescribed in our old ancient literature which need to be researched upon. Ayurveda has a big store which needs to gone through. It can be concluded that the disease is quite a complex one and requires a proper Ayurvedic approach for its better management. The anatomical and symptomatic similarities between the enlarged prostate and the Vaatastheela are quite visible and thus an approach to find deeper connection between the two and managing the condition with ayurvedic concepts is what is required.

On the basis of similarities, it can be said that the $\mathrm{Vaa}$ tastheela Vyadhi reassembles to that of enlarged prostate gland. And thus, Ayurvedic management suggested by the Acharya can be used to treat the disease by eliminating its root cause as the principle of Ayurveda is based upon these to eliminate the disease from its root. Research in the field of Ayurveda regarding the management of $\mathrm{BPH}$ is very much wanted at this time.

\section{CONCLUSION}

As it is seen that there are various complications of surgery for $\mathrm{BPH}$ so there is a wide scope of research in this field related to Ayurvedic aspect in medical management of the disease, so that we can avoid surgery and its complications in the diseased people. Various drugs are being researched in relation to $\mathrm{BPH}$ and Ayurvedic management of Vaatstheela can be further researched to find a better, convenient and simpler way to deal with the problem.

\section{REFERENCES}

1. Vaidya Jadhavji Trikamji Acharya Editor, Sushruta Samhita with commentary of Dalhana, vol 2, Uttar Tantra, Chapter -58/1, Chowkhambha Oriental Publishers, Varanasi, reprint 2008, pg- 679.

2. Dr. Suresh babu S, The principle and practice of kayachikitsa, vol- $2^{\text {nd }}$, Chapter-23 rd, Chowkhambha Oriental Publishers, Varanasi, reprint 2012; pg- 186

3. Vaidya Jadhavji Trikamji Acharya Editor, Sushruta Samhita with commentary of Dalhana, vol- 2, Uttar
Tantra, Chapter -58/18,19,20, Chowkhambha Oriental Publishers, Varanasi, reprint 2008, pg- 679, pg-824.

4. Agnivesha Revised by Charaka and dhradabala, Charaka Samhita with Ayurveda - dipika commentary of Chakrapanidatta, $4^{\text {th }}$ edition, vol-2, siddhi- sthan 9/36, Chaukhambha oriental publishers, Varanasi, reprint 1994, pg no.-951, pp-999

5. Vaidya Jadhavji Trikamji Acharya Editor, Sushruta Samhita with commentary of Dalhana, vol- 2, Uttar Tantra, Chapter -58/ 7, 8, Chowkhambha Oriental Publishers, Varanasi, reprint 2008, pg- 679, pg-824.

6. Agnivesha, Revised by Charaka and dhradabala, Charaka Samhita with Ayurveda - Ayurveda Dipika commentary of Chakrapanidatta, $4^{\text {th }}$ edition, vol-2, chikitsa sthan $26 / 32$, Chaukhambha oriental publishers, Varanasi, reprint-1994, pg no.-951, pp-999

7. Vaidya Jadhavji Trikamji Acharya Editor, Sushruta Samhita with commentary of Dalhana, vol- 2, Uttar Tantra, Chapter -58/ 27,28, Chowkhambha Oriental Publishers, Varanasi, reprint 2008, pg-824.

8. Vaidya Jadhavji Trikamji Acharya Editor, Sushruta Samhita with commentary of Dalhana, vol- 2, Uttar Tantra, Chapter -58/ 27,28, Chowkhambha Oriental Publishers, Varanasi, reprint 2008, pg-824

9. Prof. Ajay kumar Sharma, Kayachikitsa, Vol-2, chapter-50 Chowkhambha Oriental Publishers, Varanasi, reprint 2019; pg-746.

10. Chaurasiya BD, Human Anatomy Vol $-2^{\text {nd }}$, Chap -32 , CBS publishers Pvt. Ltd, New Delhi, reprinted 2010, $5^{\text {th }}$ edition, pg-403

11. M. Sriram Bhatt, SRB's Manual of Surgery, Chap-26, Jaypee brothers medical publishers limited, New Delhi, reprinted, 2010, $3^{\text {rd }}$ edition pg- 986

12. Das S, A concise textbook of Surgery, chapter-45, S. Das publishers, Kolkata, reprinted $2019,10^{\text {th }}$ edition pg1272, pg- 1358.

13. M Sriram Bhatt, SRB's Manual of Surgery, Chap- 26, Jaypee brothers medical publishers limited, New Delhi, reprinted- 2010, 3rd Edition pg-988. Pg-1198

\section{Source of Support: Nil \\ Conflict of Interest: None Declared}

How to cite this URL: Sweta Rautela: A Literary Review Of Vaatastheela Mootraghata And Its Management W.S.R BPH. International Ayurvedic Medical Journal \{online\} 2021 \{cited May, 2021\} Available from: http://www.iamj.in/posts/images/upload/1032_1036.pdf 